\title{
Process performance and microbial community functional structure in a thermophilic anaerobic baffled reactor coupled with biocatalysed electrolysis
}

\author{
Wang, Tao; Lv, Nan; Pan, Xiaofang; Li, Chunxing; Zhu, Gefu
}

Published in:

Environmental Technology (United Kingdom)

Link to article, DOI:

$10.1080 / 09593330.2018 .1540664$

Publication date:

2020

Document Version

Peer reviewed version

Link back to DTU Orbit

Citation (APA):

Wang, T., Lv, N., Pan, X., Li, C., \& Zhu, G. (2020). Process performance and microbial community functional structure in a thermophilic anaerobic baffled reactor coupled with biocatalysed electrolysis. Environmental Technology (United Kingdom), 41(12), 1535-1545. https://doi.org/10.1080/09593330.2018.1540664

\section{General rights}

Copyright and moral rights for the publications made accessible in the public portal are retained by the authors and/or other copyright owners and it is a condition of accessing publications that users recognise and abide by the legal requirements associated with these rights.

- Users may download and print one copy of any publication from the public portal for the purpose of private study or research.

- You may not further distribute the material or use it for any profit-making activity or commercial gain

- You may freely distribute the URL identifying the publication in the public portal 
Revised Manuscript (With Track Changes)

1

2 structure in a thermophilic anaerobic baffled reactor coupled with biocatalyzed electrolysis

4

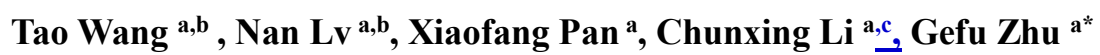

5 a. Key Laboratory of Urban Pollutant Conversion, Institute of Urban Environment,

6 Chinese Academy of Sciences, Xiamen 361021, China

7

b. University of Chinese Academy of Sciences, Beijing 100049, China

8

c. Department of Environmental Engineering, Technical University of Denmark, Kgs.

\section{$9 \quad$ Lyngby DK-2800, Denmark}

10

*Corresponding author

E-mail: gfzhu@iue.ac.cn; Tel: 86-592-6190790; Fax: 86-592-6190790 
Abstract: In this study, the performances of a conventional anaerobic baffled reactor (ABR) and an ABR combined with microbial electrolysis cells (MECs) for enhancing degradation of volatile fatty acids (VFAs) were evaluated in $55^{\circ} \mathrm{C}$. The ABR-MECs system achieved a total chemical oxygen demand (COD) removal rate of $97.2 \%$ and a methane yield of $236 \pm 5 \mathrm{~mL} / \mathrm{g}$ COD removed at organic loading rate (OLR) of $6.9 \mathrm{~kg}$ COD $\mathrm{m}^{-3} \mathrm{~d}^{-1}$, which were higher than those of the ABR with $77.6 \%$ and $207 \pm 5 \mathrm{~mL} / \mathrm{g}$


analysis confirmed that the introduction of MECs into ABR was conducive to establishing stable functional communities of syntrophic fatty acids oxidizing bacteria (SFOB), exoelectrogens and hydrogenotrophic methanogens, such as Syntrophobacter (5.4\%), Thermodesulfovibrio (2.0\%), Methanobacterium (43.8\%), Methanolinea (20.4\%). The content of unclassified bacteria increased from $12.4 \%$ in the ABR system to $52.3 \%$ in the ABR-MECs system. In contrast, the proportion of aceticlastic $\underline{\text { methanogens decreased from } 50.1 \% \text { in the ABR to } 24.5 \% \text { in the ABR-MECs system. }}$ The improved performance of thermophilic ABR-MECs system was resulted from phase separation, wide ecological niche and intensification of methanogenesis process via functional microbes, which significantly enhanced the degradation of propionic acid and acetic acid.

Key words: Anaerobic digestion; Microbial electrolysis cell; Methanogenesis; Thermophiles; Microbial community 
40

41

42

43

44

\section{Introduction}

Anaerobic digestion (AD) has been widely applied in treating organic wastewater due to its advantage in energy recovery [1,2]. Nevertheless, some challenges such as low processing capacity and instability limited its efficiency for further application [3]. Correspondingly, different methods were adopted to improve efficiency of the AD process. For instance, researchers tried to optimize the conditions via engineering control and online monitoring in the early days. Boe et al. put forward several indicators for monitoring the AD process [4]. The VFAs, especially propionic acid, were important indicators for stable operation of the AD process [5].

In recent years, bioaugmentation technology has been widely investigated and applied in the $\mathrm{AD}$ process. Generally, the metabolic rate between acidogens and methanogens is imbalanced, which resulted in instability and accumulation of VFAs [6]. In response to this problem, $\mathrm{Li}$ et al. proposed the application of bioaugmentation to prevent failure from ammonia and propionate inhibition [7]. Town and Dumonceaux made use of a small and stable consortium capable of catabolizing acetate for stimulating methanogenesis [8]. These previous studies indicated the bioaugmentation via SFOB (e.g. propionic / butyric oxidizing bacteria) and acid-resistant methanogens was a meaningful attempt to avoid excessive acidification in the AD process. Indeed, bioaugmentation technology can reconstruct microbial community, improve abundance of functional bacteria and make up the imbalance between acidogens and methanogens to certain extent. However, the traditional bioaugmentation technology was hard to 
61 make up the limitations of methanogens (e.g., long generation cycles and narrow

62 ecological niches ) with acclimation of SFOB and acid-resistant methanogens [9].

63 Besides, how to keep stable existence of functional microbes is a key issue for

64 traditional bioaugmentation.

65 Bio-electrochemical system (BES) has been a promising energy-friendly system

66 dealing with the imbalance between acidogens and methanogens via the function of

67 exoelectrogens $[10,11]$. In a MEC, exoelectrogens transfer electrons to the anode by

68 oxidizing organic matters, and the electrons pass through circuit to the cathode to

69 produce $\mathrm{H}_{2}$. Thereafter, methane can be produced in the biocathode via

70 hydrogenotrophic methanogens [12]. The previous study indicated that exoelectrogens

71 compete with methanogens for electrons, realizing the oxidation of organic matter in the

72 anode. In the cathode, exoelectrogens obtain electrons from cathode and conduct the

73 synthesis of methane via $\mathrm{H}^{+}, \mathrm{CO}_{2}$ and electrons. BES dominated by exoelectrogens has

74 lots of advantages in utilization of organic matter and biogas production. Clauwaert et al.

75 investigated one mole acetate could be converted into 0.41 mole methane at the

76 temperature ranges of $22-28{ }^{\circ} \mathrm{C}$ [13]. In addition, Hao et al. observed the

77 exoelectrogens had a better adaptability than methanogens [14]. Therefore, it is quite

78 possible to take advantage of exoelectrogens to enhance the oxidation of acetic acids

79 and methane generation, making up the imbalance of metabolic rates between acidogens

80 and methanogens. Actually, MECs have been already applied in the AD system. Overall,

81 the previous studies on the AD-MECs mainly focused on: (1) Efficiency enhancement, 
82 e.g. the improvement of methane production and energy recovery rate (Gajaraj et al., 83 2017, Hassanein et al., 2017). (2) Microbial community. The hydrogenotrophic

84 methanogens enriched in the cathode played important role in enhancing methane yield

85 (Gholikandi et al., 2014). Besides, the enrichment of exoelectrogens in the anode

86 improved the removal of organics (Cerrillo et al., 2016, Liu et al., 2017). (3) Electron

87 transfer mechanism. For instance, the zero-valent iron or suitable extra voltage

88 promoted the direct electron transfer of exoelectrogens (Zhang et al., 2013, Choi et al.,

2017). Although the enhanced efficiency of the AD system by MECs and microbial composition were mainly focused, synergistic degradation of VFA via functional bacteria has not been paid much attention. Actually, the decomposition of propionic acid and butyric acid by exoelectrogens is much slower than acetic acid (Clauwaert et al., 2008), which limits further application of the AD-MECs system. To accelerate the VFA degradation, the acclimated SFOB was applied to enhance degradation of propionic and butyric acid, further improve the removal of organics and methane production in the AD-MEC system. Through the synergistic effect of SFOB and exoelectrogens in the thermophilic condition, VFA can be fast degraded in this study.

To the best of our knowledge, bioaugmentation technology based on thermophilic SFOB and exoelectrogens for boosting degradation of VFAs has not been applied and evaluated for the AD process. And its performances and responses of microbes have not yet been explored. So, an improved ABR-MECs system was established and evaluated. 
103

104

105

106

107

108

109

110

as COD removal, methane production and indicators for stability (i.e., VFAs, $\mathrm{pH}$, alkalinity (ALK) and Oxidation-Reduction Potential (ORP). Moreover, microbial communities were analyzed to further demonstrate performance of the ABR-MECs system.

\section{Materials and methods}

\subsection{Configuration, start-up and operation of the ABR-MECs system}

The volume of the ABR is $2.5 \mathrm{~L}$ with circling hot water to keep temperature of 55

$\pm 1{ }^{\circ} \mathrm{C}$. The ABR is divided into five equal compartments by vertical baffles as shown in Fig.1. The temperature of the substrate tank was controlled by a water jacket with a cooler $\left(4{ }^{\circ} \mathrm{C}\right)$. The temperature of $\mathrm{ABR}$ was assured by water jacket and heater, and submerged thermometers were equipped to indicate the temperature in the reactors. Each compartment is divided into down-corner and up-corner regions by hanged baffles of $45^{\circ}$. The synthetic wastewater was fed via a peristaltic pump (BT100-2i, Longer Pump, Britain). The reactor is sealed and the top of each compartment is connected to a 7 L gas sampling bag for measuring the volume of biogas via a flow meter (LML-1, Changchun Automobile Filter., China). The anodes and cathodes are fixed in up-flow region of the three middle compartments and connected with power source (0.9 Volt). The start-up was performed in a conventional ABR with OLR of $1.4 \mathrm{~kg}$ COD $\underline{\mathrm{m}^{-3} \mathrm{~d}^{-1} \text {, and a stable COD removal of } 72 \pm 1 \% \text { was achieved in the end of start-up stage }}$ (Period 1, Hydraulic Retention Time $(\mathrm{HRT})=26 \mathrm{~h})$. Further COD removal was hard to 
123 be obtained when low influent COD was given as insufficient COD presumably 124 restricted the growth of sludge microorganisms. Correspondingly, OLR in the 125 conventional ABR (Period 2, HRT=21 $\underline{\mathrm{h}}$ ) climbed up from 1.7 to $5.1 \mathrm{~kg} \mathrm{COD} \mathrm{m} \mathrm{d}^{-1}$.

126

127 However, when OLR was $5.1 \mathrm{~kg} \mathrm{COD} \mathrm{m}^{-3} \mathrm{~d}^{-1}$, the COD removal rate decreased significantly (Fig. 2d) and VFAs were accumulated in the fifth compartment (Fig.3, 5b). Therefore, MECs were introduced into the traditional ABR by inserting electrodes with applied voltage, which was made as described in Section 2.3 to enhance the degradation of VFAs after 28 days operation of Period 2. Meanwhile, the sludge contained SFOB and exoelectrogens acclimated in the Section 2.3 were inoculated to accelerate the process of the ABR-MECs system. Therefore, the anaerobic process was defined into three periods. The first period was the start-up stage under low OLR in the ABR system. The second period was the operational stage in the ABR system. And the third period $\underline{\text { was operational stage after the electrodes inserting into the ABR system (ABR-MECs }}$ system). The introduction of MECs built a suitable electrochemical environment for stable existence of exoelectrogens. The operation of the ABR-MECs system started with OLR of $5.1 \mathrm{~kg}$ COD m $\mathrm{m}^{-3} \mathrm{~d}^{-1}$ and finally increased to $6.9 \mathrm{~kg} \mathrm{COD} \mathrm{m}^{-3} \mathrm{~d}^{-1}$ (Period 3, HRT $=21 \mathrm{~h}$ ). The operation lasted for 72 days as described in Table 1.

Fig.1. Process flow schematic of the ABR-MECs system. Table 1 Operation of the conventional ABR and ABR-MECs systems

\subsection{Characteristics of wastewater and inoculated sludge}

The study aimed to verify the feasibility of boosting VFAs degradation by SFOB 
and exoelectrogens. So, glucose was applied as single carbon source to reduce interference factors in the experiment. The $\mathrm{NH}_{4} \mathrm{Cl}$ and $\mathrm{KH}_{2} \mathrm{PO}_{4}$ were provided as nitrogen and phosphorus sources. In addition, the $\mathrm{NaHCO}_{3}$ was given to regulate $\mathrm{pH}$ value. The concentration of synthetic wastewater was prepared according to Table 1 . Constant element and mineral solution of $1.5 \mathrm{mLL}^{-1}$ was also added as nutrients based on our previous study [21]. It was prepared by dissolving $50 \mathrm{mgL}^{-1} \mathrm{H}_{3} \mathrm{BO}_{3}, 30 \mathrm{mgL}^{-1}$ $\mathrm{CuCl}_{2}, 50 \mathrm{mgL}^{-1} \mathrm{MnSO}_{4}, 50 \mathrm{mgL}^{-1}\left(\mathrm{NH}_{4}\right)_{6} \mathrm{MoO}_{24} \cdot 4 \mathrm{H}_{2} \mathrm{O}, 50 \mathrm{mLL}^{-1} \mathrm{AlCl}_{3}, 50 \mathrm{mgL}^{-1}$ $\mathrm{CoCl}_{2} \cdot 6 \mathrm{H}_{2} \mathrm{O}$ and $50 \mathrm{mgL}^{-1} \mathrm{NiCl}_{2}$ in the distilled water. Seed sludge of ABR was obtained from an anaerobic digester treating filtrate from hydrothermally treated sewage sludge [22]. The seed sludge in each compartment of reactor was about half of the working volume ( $0.5 \mathrm{~L}$ per compartment). SS and VSS of Seed sludge were $31.2 \mathrm{gL}^{-1}$ and $12.5 \mathrm{gL}^{-1}$, respectively.

\subsection{Pre-acclimation of exoelectrogens and SFOB in static experiment}

Exoelectrogens were pre-acclimated in microbial fuel cells (MFCs). The beaker with $500 \mathrm{~mL}$ volume was applied to constitute a single chamber MFC. Resistance of $1000 \Omega$, electrode film and substrate were formed together as a circuit. Sodium acetate was added as carbon sources to provide COD with concentration of $4000 \mathrm{mgL}^{-1}$ while $50 \mathrm{mM}$ phosphate buffer nutrient medium was applied to sustain $\mathrm{pH}$ value of 7.0. $\underline{\mathrm{A}}$ mineral solution of $1.5 \mathrm{mLL}^{-1}$ was also added as nutrient based on our previous study [21]. The electrode was $54.0 \mathrm{~cm}^{2}$ with $6.0 \mathrm{~cm}$ in width and $9.0 \mathrm{~cm}$ in length. The anodes and cathodes were made of carbon cloth (WOS1009, CeTech, Taiwan) and stainless 
164

steel mesh catalyzed by $\mathrm{Ni}$ nanoparticles, respectively. Six parallel groups were executed in $55 \pm 1^{\circ} \mathrm{C}$. One cycle was finished when COD removal rate was higher than $80 \%$ and then substrate was replaced to begin another cycle. Stable voltage higher than $300 \mathrm{mV}$ was generated by MFCs after 5 cycles, indicating that electrodes with enriched exoelectrogens were well prepared. More detail about the modified method of cathodes and procedure of exoelectrogens acclimation can be found in our previous article [21].

The SFOB was acclimated in anaerobic bottles. Sodium propionate and sodium butyrate were applied in equal amount as carbon sources to provide COD with concentration of $4000 \mathrm{mgL}^{-1}$. The proportion of COD: N: P was 500: 5: 1 . A mineral solution of $1.5 \mathrm{mLL}^{-1}$ was also added as nutrients based on our previous study [16]. Six parallel groups were executed in $55 \pm 1{ }^{\circ} \mathrm{C}$. Substrate was updated every 7 days. After five cycles, the COD removals were more than $93.8 \%$. Besides, butyrate was not detected and the removal rate of propionate was $98.2 \%$, suggesting the acclimated sludge with enriched SFOB was well prepared.

In order to construct an improved ABR-MECs system for enhancing the degradation of VFAs, the acclimated sludge containing $60 \%$ exoelectrogens and $40 \%$ (V/V) SFOB was inoculated into the middle three compartments as soon as electrodes inserted into the ABR system after operation of Period 2. The proportion of inoculation was $5 \%(\mathrm{~V} / \mathrm{V})$ working volume $(0.5 \mathrm{~L})$ of per compartment. Besides, in order to keep the sludge of system consistent, equivalent original sludge was removed before inoculation. 


\subsection{Analytical methods}

Effluent samples from each reactor and substrate were taken from the sampling ports based on HRT. All chemical analyses of effluent such as $\mathrm{pH}$, alkalinity, COD were followed Standard Methods [23]. The VFAs and biogas were measured via a gas chromatograph (GC9790II, Fuli, China) with He as the carrier gas and hydrogen for burning of the flame. The VFAs were measured with a flame ionization detector using a capillary column (ATFFAP $30 \mathrm{~m} \times 0.32 \mathrm{~mm} \times 0.50 \mu \mathrm{m}$ ), and the temperature of column, injector, and detector were $150{ }^{\circ} \mathrm{C}, 210{ }^{\circ} \mathrm{C}$, and $220^{\circ} \mathrm{C}$, respectively. The biogas was monitored with a thermal conductivity detector equipped with a stainless steel column (TDX-01 $2 \mathrm{~m} \times 3 \mathrm{~mm}$ ), and the temperature of column, injector, and detector were $120{ }^{\circ} \mathrm{C}, 120{ }^{\circ} \mathrm{C}$ and $150{ }^{\circ} \mathrm{C}$, respectively. Gas sample was taken from each gas pipeline by a $1 \mathrm{~mL}$ syringe equipped with metal hub needles to measure the gas composition. A volume of $0.5 \mathrm{~mL}$ of gas sample was injected into the gas chromatograph. Microorganisms in sludge and electrodes were also observed by scanning electron microscope (S-4800, Hitachi, Japan). The samples were prepared according to following method [21]: first, samples were fixed by $2.5 \%$ solution of paraformaldehyde for $0.5 \mathrm{~h}$, and then dehydrated by ethanol series of $50 \%, 70 \%, 80 \%$, $90 \%$ and $100 \%(\mathrm{v} / \mathrm{v})$ for $0.5 \mathrm{~h}$ each time, and subsequently dried by a critical point dryer (HCP-2, Hitachi, Japan). Data in the steady state were collected at least three times. The average values of these measurements are presented in Table 2. 
conventional ABR) and days 70 (only biofilm of both anodes and cathodes in the

207

208

209

210

211

212

213

214

215

216

217

218

219

220

221

222

223

224

225

ABR-MECs system) were collected to analyze microbial communities via high-throughput 16S rRNA pyrosequencing. The samples collected from anodes were $\underline{\text { mixed to extract DNA for three times and then the DNA samples were mixed to conduct }}$ $\underline{\text { the high-throughput } 16 \mathrm{~S} \text { rRNA pyrosequencing. The samples collected from cathodes }}$ and the ABR system were handled as those of anodes. DNA was extracted by FastDNA TM SPIN Kit for Soil (MP Biomedicals, USA). The V3-V4 region of 16S rRNA gene was amplified by PCR using the primers $341 \mathrm{~F}$ (CCTACGGGNGGCWGCAG), $785 \mathrm{R}$ (GACTACHVGGGTATCTAATCC) for bacteria and the primers 787 (ATTAGATACCCSBGTAGTCC), $1059 \mathrm{R}$ (GCCATGCACCWCCTCT) for archaea. Additional information about DNA extraction, PCR and sequencing can be found elsewhere [24]. The raw sequence data were deposited in the NCBI Short Reads Archive database under the accession number SRP150392.

\section{Results}

\subsection{The COD removal efficiency}

The COD removal efficiency in different stages is showed in Fig.2 (d). The growing influent COD in the conventional ABR (Period 2) led to a rapid increase of total COD removal rate of $95.3 \%$ when influent COD was $3500 \mathrm{mgL}^{-1}$. Therefore, enough nutrients with moderate alkalinity were beneficial to the operation of ABR.

Nevertheless, the COD removal rate decreased significantly as influent COD climbed 
up to $4500 \mathrm{mgL}^{-1}$ with OLR of $5.1 \mathrm{~kg} \mathrm{COD} \mathrm{m}^{-3} \mathrm{~d}^{-1}$. And $77.6 \%$ of COD removal rate

227 was detected in the conventional $\mathrm{ABR}$ in the end of Period 2 regardless of adequate ALK. Accordingly, the concentration of VFAs (Fig.3 1b-5b) indicated that propionic $\underline{\text { acid and acetic acid were dominant in the conventional ABR, causing fast growing of }}$ effluent COD. The phenomenon indicated the ABR system was in a critical stable state accompanied with the occurrence of propionic accumulation in Day 45. It was benefited $\underline{\text { to the investigation on propionic degradation when electrodes were inserted at this time. }}$ Therefore, the operation of conventional ABR was stopped and further modified by $\underline{\text { inserting electrodes and inoculating enriched SFOB and exoelectrogens to establish an }}$ improved ABR-MECs system. After modification, the total COD removal rate of the ABR-MECs system increased to $97.2 \%$ when the OLR was up to $6.9 \mathrm{~kg} \mathrm{COD} \mathrm{m}^{-3} \mathrm{~d}^{-1}$, $19.6 \%$ higher than that of conventional ABR with OLR of $5.1 \mathrm{~kg} \mathrm{COD} \mathrm{m}^{-3} \mathrm{~d}^{-1}$. Besides, the COD removal rates in five compartments were $54.3 \%, 36.7 \%, 2.2 \%, 2.3 \%$ and $1.8 \%$, respectively, while those in the ABR were $29.1 \%, 18.4 \%, 13.9 \%, 9.2 \%$ and $7.1 \%$, correspondingly. Clearly, the COD removal efficiencies were promoted in front parts of ABR-MECs system. The pollutant removal capacity was significantly enhanced in the ABR-MECs system. The improved performance was due to further degradation of VFAs (Fig.3, 1-5a). Specifically, both acetate and propionate were reduced significantly in the ABR-MECs system. 
Fig.3. Contrast of VFAs in (a) the ABR-MECs, (b) conventional ABR.

\subsection{The methane content performance}

Average contents of methane in the first to fourth compartments were $56.3 \%$, $63.7 \%, 66.2 \%$ and $73.8 \%$, respectively, in the stable stage of the ABR system. In contrast, Average contents of $58.6 \%, 72.8 \%, 80.9 \%$ and $83.5 \%$ were detected correspondingly in the stable stage of the ABR-MECs system. The maximum content of $\mathrm{CH}_{4}(83.5 \%)$ in biogas was detected in $\mathrm{C} 4$ with a total production rate of $236 \pm 5 \mathrm{~mL}$ $\mathrm{CH}_{4} / \mathrm{g}$ COD removed in the ABR-MECs system. The maximum content of $\mathrm{CH}_{4}$ in conventional ABR was $73.8 \%$ and the total production rate was $207 \pm 5 \mathrm{~mL} \mathrm{CH}_{4} / \mathrm{g} \mathrm{COD}$ removed. Besides, contents of $\mathrm{CO}_{2}$ in the middle three compartments (MECs) were $25.3 \%, 17.6 \%$ and $14.2 \%$, respectively, while those of conventional ABR were $30.4 \%$, $27.3 \%$ and $25.7 \%$, correspondingly. More net methane and less carbon dioxide were detected in the ABR-MECs system when compared with the ABR system. They were also higher than the previous study [25], in which methane content was usually from $50 \%$ to $75 \%$ while the carbon dioxide content was from $25 \%$ to $50 \%$ in the $\mathrm{AD}$ system. The results indicated that energy production was enlarged in the ABR-MECs system.

\subsection{The characteristics of $\mathrm{ORP}$, alkalinity and $\mathrm{pH}$ values}

The ORP, alkalinity and $\mathrm{pH}$ values were important indicators of stability in the anaerobic system and their changes were depicted in Fig.2 (a-c). The ORP is one of key factors influencing acid fermentation types and methane production. As can be seen in Fig. 2a, the range of ORP in the ABR-MECs system is between $-240 \mathrm{mV}$ and $-280 \mathrm{mV}$. 
Notably, it is higher than the ORP with the range of $-280 \mathrm{mV}$ to $-320 \mathrm{mV}$ in the ABR system. Higher ORP was obtained in the ABR-MECs system to produce methane than other results made by Khanal and Huang [26], who observed that the best ORP for $\underline{\text { methanogens was }-350 \mathrm{mV} \text {. Besides, the ORP of the middle three compartments (MECs }}$ parts) were higher than the first and last compartment in the ABR-MECs system. It indicated that the introduction of MEC increased the ORP of the AD system. As for alkalinity and $\mathrm{pH}$, the influent alkalinity in the conventional ABR (Period 2) grew fast to keep enough buffer capability. In the ABR-MECs (Period 3), higher effluent alkalinity $\left(2912.9 \mathrm{mgL}^{-1}\right)$ was detected with lower influent alkalinity $\left(2900 \mathrm{mgL}^{-1}\right)$ when compared with the corresponding $2769.6 \mathrm{mgL}^{-1}$ and $3200 \mathrm{mgL}^{-1}$ in the conventional ABR. The $\mathrm{pH}$ values of the middle three compartments grew up from 6.9 7.1 to $7.2-7.3$ when the ABR transformed to ABR-MECs system.

\subsection{Microorganisms morphology analysis}

The sludge in the conventional ABR and ABR-MECs systems were analyzed by SEM to characterize the structure and morphology, as showed in Fig. 4. The major species of $\mathrm{C} 2-\mathrm{C} 4$ changed from globular bacteria in the ABR to bacillus of anodes in the ABR-MECs system, revealing difference of functional microbes in the methanogenic phase. Notwithstanding, there was no distinct change of microorganism morphology in the $\mathrm{C} 1$, suggesting that the main functional microorganism in the acidogenic phase did not change much between the ABR and ABR-MECs system. It was consistent with the results obtained by Liu et al.[27], who found that shot rod-shaped and filamentous 
289

290

291

292

293

294

295

296

297

298

299

300

301

302

303

304

305

306

307

308

309

bacteria in initial compartment of the ABR were responsible for hydrolysis and acidification. Clearly, the electrochemical system only changed microbial communities of methanogenic phase in the ABR-MECs system, making it more effective in degradation of product from acidification. Particularly, microbial community would be further analyzed in the pyrosequencing analysis.

Fig.4. Photograph of scanning electron microscope: (a) 01, sample from C1 in the ABR stage, (a) 02, sample from C1 in the ABR-MECs stage, (b) 01, sample from C2-C4 in the ABR stages, (b) 02, sample from anodes in the ABR-MECs stage.

\subsection{Pyrosequencing analysis.}

Pyrosequencing analysis was performed to find the specific difference of microbial communities between the conventional ABR and ABR-MECs systems. Communities of functional eubacteria at phylum level in the ABR and ABR-MECs systems were described in Fig.6. Although the studies on the microorganism of integrated AD-MEC system were the research hot spot, the achievement of thermophilic condition are relatively deficient. However, some comparisons can still be found. (1) The dominant bacteria in both ABR and ABR-MECs systems were Firmicutes and Proteobacteria with contents of $14.7 \%$ and $9.8 \%$ in the ABR-MECs system, and $49.0 \%$ and $16.5 \%$ in the ABR system. The analysis of microbial was in agreement with the previous studies $[28,29]$ that Firmicutes was dominant in the thermophilic electrochemical system and thermophilic anaerobic system. The difference lies in a large increase of Firmicutes in the ABR-MECs system. It further proved the significance of Firmicutes in the 
thermophilic electrochemical system. In order to find the further difference between

311 these two systems, eubacteria at genus level were described in Fig.5 (b). (2) The

312 potential exoelectrogens, a significant growth of Thermodesulfovibrio [30] was found in the ABR-MECs system with proportion of $2.01 \%$ when it was not detected in the ABR system. It was different from other thermophilic system [18] that Desulfuromonadaceae was the most active family in a thermophilic MEC. Furthermore, Geobacter, one kind of main exoelectrogens discovered in the mesophilic MECs system, was completely disappeared in the thermophilic ABR-MECs system. It's worth noting that the proportion of Unclassified bacteria in the ABR-MECs system was nearly 5 times

$319(52.6 \%)$ of that in the ABR system. All these finding further indicated the complexity of thermophilic electrochemical system, and the physiological characteristics of thermophilic exoelectrogens remained to be further studied. On the other hand, the content of Syntrophobacter, one of SFOB that made use of propionate, was promoted $272.4 \%$ in the ABR-MECs system, accounting for the effective degradation of propionic acid in the ABR-MECs system. The increased abundance of Syntrophobacter, Thermodesulfovibrio and Unclassified bacteria further confirmed that the introduction of MECs into ABR system was conducive to establishing stable communities of exoelectrogens and SFOB in the anode. 


\section{Revised Manuscript (With Track Changes)}

331 Methanobacterium, one kind of hydrogenotrophic methanogens, was detected at $43.8 \%$

332 of archaea in the ABR-MECs system, which was nearly double of those in the 333 conventional ABR system. The abundance of Methanolinea (20.4\%) in the ABR-MECs 334 system, one of hydrogenotrophic methanogens, is 10 times of that in the ABR. This 335 finding suggested that both hydrogenotrophic methanogens were well enriched in the cathode of ABR-MEC system. In contrast, the proportion of aceticlastic methanogens 337 decreased from $50.1 \%$ in the ABR to $24.5 \%$ in the ABR-MECs system. The increase of hydrogenotrophic methanogens and exoelectrogens as well as decrease of aceticlastic methanogens made fewer generation of $\mathrm{CO}_{2}$, building up the biological basis of purification of methane in site.

Fig.5 Genus of Archaea and Eubacteria in both ABR and ABR-MECs systems: (a)

Archaea of middle three compartments in the ABR system and archaea of cathodes in the ABR-MECs system; (b) Eubacteria of middle three compartments in the ABR system and Eubacteria of anodes in the ABR-MECs system.

Fig.6 Relative abundances of functional microbes in both ABR and ABR-MECs systems:

Table 2 Process performance for the thermophilic ABR and ABR-MECs systems in the stable state

\section{Discussion}

In this study, an effective AD-MECs process was established to accelerate 


\section{Revised Manuscript (With Track Changes)}

350

351

352

353

354

355

356

357

358

359

360

361

362

363

364

365

366

367

were depicted in Table 2. The new system has a better efficacy than traditional ABR system in COD removal and methane production. Besides, the performance was also better than the results of previous study [31], in which COD removal rate was $68 \%$ $-72 \%$ with influent COD concentration of $5000 \mathrm{mgL}^{-1}$ and HRT of $120 \mathrm{~h}$ at operational temperatures of $37^{\circ} \mathrm{C}$ and $55^{\circ} \mathrm{C}$, respectively. The improved performance was resulted from further degradation of VFAs (Fig.3, 1-5a). The total VFAs in five compartments were $4107.3 \mathrm{mgL}^{-1}, 3169.2 \mathrm{mgL}^{-1}, 1938.8 \mathrm{mgL}^{-1}, 1179.2 \mathrm{mgL}^{-1}$ and $869.4 \mathrm{mgL}^{-1}$, respectively, in the conventional $\mathrm{ABR}$. In contrast, a sharp decrease was sketched in the ABR-MECs system, about $63.0 \%$ drop of VFAs was detected in effluent. Specifically, both acetate and propionate were reduced significantly in the ABR-MECs system. It is consistent with the previous studies that propionic acid can be fast oxidized into acetic acid by propionate oxidation bacteria in the AD process [32] and the concentration of acetic acid had a substantial decrease in the MECs system [33]. The results further indicated that SFOB and exoelectrogens performed well in the ABR-MECs system. As an evidence, the Syntrophobacter (5.4\%), Thermodesulfovibrio (2.0\%), Methanobacterium (43.8\%), Methanolinea (20.4\%) were well enriched in the ABR-MECs system as showed in Fig.5. Thus, it was an effective way to improve COD removal efficiency by enriching both SFOB and exoelectrogens in the anode, making the new system better adapt to propionic acid fermentation.

As for methane production, more methane and less carbon dioxide were achieved in the ABR-MECs system and the advantages were still obvious when compared with 
371 other AD process. The content of $\mathrm{CH}_{4}$ was $73.0 \%-75.4 \%$ in a pilot-scale UASB [34]

372 and $180 \mathrm{~mL} \mathrm{CH}_{4} / \mathrm{g}$ COD removed was detected by Wirth et al. [31]. The results in Table

3732 indicated that more and purer methane $\left(236 \mathrm{~mL} \mathrm{CH}_{4} / \mathrm{g}\right.$ COD removed) was generated

374 in the ABR-MECs system. One direct reason was that the abundance of 375 hydrogenotrophic methanogens (67.2\%) in the ABR-MECs system, which were nearly

376 double of that $(37.5 \%)$ in the ABR system as depicted in Fig.6. They were also

377 significantly higher than the traditional AD system in which aceticlastic methanogens 378 were dominant in the methanogenic process. The significant increase of 379 hydrogenotrophic methanogens can be due to the enhanced production of $\mathrm{H}_{2}$ by exoelectrogens [35]. In all, the exoelectrogens boosted the degradation of acetic acid, removed acetic inhibition for SFOB and simultaneously promoted the abundance of hydrogenotrophic methanogens and generation of methane.

Nevertheless, If it was the only way consuming hydrogen via hydrogenotrophic methanogens, hydrogen should be detected in the system, as hydrogenotrophic methanogens cannot completely remove hydrogen if methane production was only caused by converting hydrogen [36]. In fact, hydrogen was not discovered in the

ABR-MECs system. There may be other ways to generate methane in the ABR-MECs system. The electrochemical systems offer possibilities for new methanogenic pathways.

The exoelectrogens were defined as a kind of microorganisms with extracellular 
393 detected at $43.83 \%$ of archaea in the cathodes of the ABR-MECs system, which was

394 nearly double of the ABR as described in Fig.5 (a). Correspondingly, more $\mathrm{CO}_{2}$ was

fixed in site realizing the purification of methane [38].The significance of

Methanobacterium discovered in cathodes not only certified such a new way to generate

methane but also proved that it can play a leading role in certain conditions. Thus,

higher content of methane in the ABR-MECs system was resulted from enrichment of hydrogenotrophic methanogens and methanogens with electrochemical active (e.g.

Methanobacterium) in the cathodes. It is an effective way to improve generation of methane by coupling biocatalyzed electrolysis reactor with conventional AD process. the ABR-MECs system originated from two aspects: (1) organic matters that hard to utilized (i.e., propionic acid, butyric acid) were fast degraded to acetic acid by SFOB and in turn exploited by exoelectrogens in the anode; (2) Electrons in the cathode obtained by exoelectrogens directly or transformed to $\mathrm{H}_{2}$ and then made use by hydrogenotrophic methanogens to produce methane. The existent of SFOB reduced the accumulation of propionic acid and provided enough substrate for exoelectrogens. The consumption of acetic acid by exoelectrogens not only removed the acetic inhibition of

410 SFOB, but also promoted the enrichment of the hydrogenotrophic methanogen.

411 Therefore, the SFOB and exoelectrogens were the most important functional microorganisms in the ABR-MECs system to realize fast degradation of VFAs. 


\section{Revised Manuscript (With Track Changes)}

413

414

415

416

417

418

419

It is worth noting that the purer methane was generated stably in the ABR-MECs system when ORP was in the ranges of $-250 \mathrm{mV} \sim-280 \mathrm{mV}$. Higher ORP was obtained to produce methane compared with conventional ABR and other results made by Khanal and Huang [26], who observed that the best ORP for methanogens was $-350 \mathrm{mV}$, meaning wider ecological niche in the ABR-MECs system [39]. Wang et al. found that maximum electric current was generated in a modified MFC with ORP of $-219 \mathrm{mV}$. The finding demonstrated the exoelectrogens can adjust themselves well in high ORP [39]. Thus, methane can be produced without such strict anaerobic conditions as conventional ABR did, facilitating the running of anaerobic system. It may be a practical advantage in further application of the AD-MECs system. Besides, high ALK and $\mathrm{pH}$ values resulted from efficient degradation of VFAs were considered to other factors which were beneficial to the stability of system [21]. It was reported by Gil et al. that MFC achieved a maximum current density with an optimal $\mathrm{pH}$ range of $7.0-8.0$ [40], while O'Flaherty et al. reported that the growth rates of methanogens could be inhibited when pH was above 7.5 or below 7.0 [41]. Therefore, $\mathrm{pH}$ level of 7.2 - 7.3 in the MECs parts of the ABR-MECs system were in favor of methane production. Consequently, a wide ecological niche containing suitable ALK, $\mathrm{pH}$ and wide range of ORP was the chemical foundation of the ABR-MECs system to perform well in the COD removal and methane production.

In a traditional $\mathrm{AD}$ process, methanogenesis was the speed-limiting step and unbalanced metabolic rate between methanogens and acidogens resulted in poor 
434 treatment and unstable performance. In the ABR-MECs system, middle three

435 compartments were coupled with electrodes to produce methane while the first

436 compartment performed as acidogenic phase, making them more integral and effective.

437 Favorable structure of ABR realized cascade-utilization of organic matter in different

438 units with phase separation. Similar research was conducted by Cusick et al.[42], who

439 coupled several electrodes in series as an integral MEC in pilot scale and obtained better

440 efficiency. The better performance of the ABR-MECs system fundamentally originated

441 from phase separation, wide ecological niche and synergistic degradation of VFAs via

442 SFOB, exoelectrogens and hydrogenotrophic methanogens.

443 5. Conclusion

$444 \quad$ Biocatalyzed electrolysis significantly improved the performance of anaerobic 445 system in organic removal efficiency and methane production. More importantly, 446 microbial analysis certified that, it was the synergy effect of exoelectrogens and SFOB

447 in the anode correspondingly with hydrogenotrophic methanogens and methanogens 448 with electrochemical activity in the cathode achieved rapid degradation of organic 449 matter and considerable methane production in the new system. These finding further 450 confirmed that it provided an insight into methanogenic steps from cascade degradation 451 of VFAs by the SFOB, exoelectrogens and hydrogenotrophic methanogens. 


\section{Revised Manuscript (With Track Changes)}

454 The authors would like to thank the supports from the National Key Research and

455 Development Program of China (Contract No. 2017YFD0800804-03), the National

456 Natural Science Foundation of China (Contract No. 21477122, 51678553, 21276248),

457 the Project of the Natural Science Foundation of Fujian Province (Contract No.

458 2016J01273, 2017J05092), IUE CAS Young Talents Frontier Project (Contract No.

459 IUEQN201501) and the Japanese - China Research Cooperative Program (Contract No.

460 2016YFE0118000).

461 Conflict of interest

462 The authors declare that they have no conflict of interest.

\section{Reference:}

464

465

466

467

[1] Aboudi K, Álvarez-Gallego CJ, Romero-García LI. Influence of total solids concentration on the anaerobic co-digestion of sugar beet by-products and livestock manures. Sci. Total Environ. 2017,586, 438-445. https://doi.org/ 10.1016/j.scitotenv.2017.01.178

[2] Sung H, Katsou E, Statiris E, et al. Operation of a modified anaerobic baffled reactor coupled with a membrane bioreactor for the treatment of municipal wastewater in Taiwan. Environ. Technol. 2018, (8):1-6. https://doi.org/10.1080/09593330.2017.1420102

[3] Clark IC, Zhang RH, Upadhyaya SK. The effect of low pressure and mixing on biological hydrogen production via anaerobic fermentation. Int. J. Hydrogen Energy, 2012, 37(15): 11504-11513. https://doi.org/10.1016/j.ijhydene.2012.03.154

[4] Boe K, Batstone DJ, Steyer J.P., et al. State indicators for monitoring the anaerobic digestion process. Water Res. 2010, 44(20), 5973-5980. https://doi.org/10.1016/j.watres.2010.07.043 


\section{Revised Manuscript (With Track Changes)}

475 [5] Pullammanappallil PC, Chynoweth DP, Lyberatos G., et al. Stable performance of anaerobic digestion in the presence of a high concentration of propionic acid. Bioresour. Technol. 2001, 78(2), 165-169. https://doi.org/10.1016/S0960-8524(00)00187-5

[6] Liu X, Dong B, Dai X. Hydrolysis and acidification of dewatered sludge under mesophilic, thermophilic and extreme thermophilic conditions: effect of pH. Bioresour. Technol.2013, 148(8), 461-466. https://doi.org/10.1016/j.biortech.2013.08.118

[7] Li Y, Zhang Y, Sun Y, et al. The performance efficiency of bioaugmentation to prevent anaerobic digestion failure from ammonia and propionate inhibition. Bioresour. Technol. 2017, 231, 94-100. https://doi.org/10.1016/j.biortech.2017.01.068

[8] Town JR, Dumonceaux TJ. Laboratory-scale bioaugmentation relieves acetate accumulation and stimulates methane production in stalled anaerobic digesters. Appl. Microbiol. Biotechnol. 2016, 100(2), 1009-1017. https://doi.org/ 10.1007/s00253-015-7058-3

[9] Fotidis IA, Treu L, Angelidaki I. Enriched ammonia-tolerant methanogenic cultures as bioaugmentation inocula in continuous biomethanation processes. J. Cleaner Prod. 2017, 166, https://doi.org/1305-1313. 10.1016/j.jclepro.2017.08.151

[10] Chen D, Wei L, Zou Z, et al. Bacterial communities in a novel three-dimensional bioelectrochemical denitrification system: the effects of ph. Appl. Microbiol. Biotechnol. 2016, 100(15), 6805-6813. https://doi.org/10.1007/s00253-016-7499-3

[11] Li M, Pan Y, Huang L, et al. Continuous flow operation with appropriately adjusting composites in influent for recovery of $\mathrm{Cr}(\mathrm{VI}), \mathrm{Cu}(\mathrm{II})$ and $\mathrm{Cd}(\mathrm{II})$ in self-driven MFC-MEC system. Environ. Technol. 2016, 38(5):615-628. https://doi.org/10.1080/09593330.2016.1205149 


\section{Revised Manuscript (With Track Changes)}

496

497

498

499

500

501

502

503

504

505

506

507

508

509

510

511

512

513

514

515

516

[12] Choi KS, Kondaveeti S, Min B. Bioelectrochemical methane (CH4) production in anaerobic digestion at different supplemental voltages. Bioresour. Technol.2017, 245, 826-832.

$$
\text { https://doi.org/10.1016/j.biortech.2017.09.057. }
$$

[13] Clauwaert P, Tolêdo R, Van $\mathrm{dHD}$, et al. Combining biocatalyzed electrolysis with anaerobic digestion. Water Sci. Technol.2008, 57(4), 575-579. https://doi.org/10.2166/wst.2008.084

[14] Hao X, Cai Z, Fu K, et al. Distinguishing activity decay and cell death from bacterial decay for two types of methanogens. Water Res.2012, 46(4), 1251-1259.

$$
\text { https://doi.org/10.1016/j.watres.2011.12.029 }
$$

[15] Gajaraj S, Huang Y, Zheng P, et al. Methane production improvement and associated $\underline{\text { methanogenic assemblages in bioelectrochemically assisted anaerobic digestion. Biochem. Eng. }}$

$$
\text { J., 2017, 117, 105-112. https://doi.org/10.1016/j.bej.2016.11.003 }
$$

[16] Hassanein A, Witarsa F, Guo X, et al. Next generation digestion: complementing anaerobic digestion (AD) with a novel microbial electrolysis cell (MEC) design. Int. J. Hydrogen Energ., 2017,42(8), 28618-28689. https://doi.org/10.1016/j.ijhydene.2017.10.003

[17] Gholikandi GB, Jamshidi S. Methane Production Yield and Performance Assessment of Conventional and Electrolysis-Enhanced ABR (EABR). Methanogenesis: Biochemistry, Ecological Functions, Natural and Engineered Environments. 2014.

[18] Cerrillo M, Vinas M, Bonmati A. Unravelling the active microbial community in a thermophilic $\underline{\text { anaerobic digester-microbial electrolysis cell coupled system under different conditions. Water }}$ Res., 2016, 110, 192-201. https://doi.org/10.1016/j.watres.2016.12.019

[19] Liu H, Leng F, Guan Y, et al. Simultaneous Pollutant Removal and Electricity Generation in a 
Revised Manuscript (With Track Changes)

517

518

519

Combined ABR-MFC-MEC System Treating Fecal Wastewater. Water Air Soil Poll., 2017. 228(5):179. https://doi.org/10.1007/s11270-017-3342-4

[20] Zhang J, Zhang Y, Quan X, et al. Effects of ferric iron on the anaerobic treatment and microbial biodiversity in a coupled microbial electrolysis cell (MEC)--anaerobic reactor. Water Res., 2013, 47(15), 5719-5728. https://doi.org/10.1016/j.watres.2013.06.056

[21] Zou R, Zhu G, Kumar JA, et al. Hydrogen and methane production in a bio-electrochemical system assisted anaerobic baffled reactor. Int. J. Hydrogen Energy, 2014, 39(25), 13498-13504. https://doi.org/10.1016/j.ijhydene.2014.02.086

[22] Li C, Wang X, Zhang G, Li C, et al. A process combining hydrothermal pretreatment, anaerobic digestion and pyrolysis for sewage sludge dewatering and co-production of biogas and biochar: Pilot-scale verification. Bioresour. Technol.2018, 254, 187-193. https://doi.org/10.1016/j.biortech.2018.01.045

[23] APHA, AWWA and WEF (2012). Standard Methods for the Examination of Water and Wastewater. 22nd ed. Washington: American Public Health Association. http://www.standardmethods.org/

[24] Qiao M, Qu Y, Shen W, et al. Bacterial community compositions of coking wastewater treatment plants in steel industry revealed by Illumina high-throughput sequencing. Bioresour. Technol.2015, 179, 436-443. https://doi.org/10.1016/j.biortech.2014.12.041

[25] Wagner RC, Regan JM, Oh SE, et al. Hydrogen and methane production from swine wastewater using microbial electrolysis cells. Water Res.2009, 43(5), 1480-1488. https://doi.org/10.1016/j.watres.2008.12.037 


\section{Revised Manuscript (With Track Changes)}

538

539

540

541

542

543

544

545

546

547

548

549

550

551

552

553

554

555

556

557

558

[26] Khanal SK, Huang, JC. ORP-based oxygenation for sulfide control in anaerobic treatment of high-sulfate wastewater. Water Res.2003, 37(9), 2053-2062. https://doi.org/10.1016/S0043-1354(02)00618-8

[27] Liu R, Lu X, Tian Q, et al. The performance evaluation of hybrid anaerobic baffled reactor for treatment of PVA-containing desizing wastewater. Desalination, 2011, 271(1-3), 287 294. https://doi.org/10.1016/j.desal.2010.12.044

[28] Jong BC, Kim BH, Chang IS, et al. Enrichment, Performance and Microbial Diversity of a Thermophilic Mediatorless Microbial Fuel Cell. Environ. Sci. Technol.2006, 40(20), 6449-6454. https://doi.org/10.1021/es0613512

[29] Greses S, Gaby JC, Aguado D, et al. Microbial community characterization during anaerobic digestion of Scenedesmus spp. under mesophilic and thermophilic conditions. Algal Res.2017, 27, 121-130. https://doi.org/10.1016/j.algal.2017.09.002

[30] Bergua M, Levy I, Casamitjana R, et al. Exoelectrogens in microbial fuel cells toward bioelectricity generation: a review. Int. J. Energy Res.2015, 39(8), 1048-1067. https://doi.org/10.1002/er.3305

[31] Wirth B, Reza T, Mumme J. Influence of digestion temperature and organic loading rate on the continuous anaerobic treatment of process liquor from hydrothermal carbonization of sewage sludge. Bioresour. Technol.2015, 198(4), 215-222.

https://doi.org/10.1016/j.biortech.2015.09.022

[32] Li Y, Zhang Y, Kong X, Li L, et al. Effects of ammonia on propionate degradation and microbial community in digesters using propionate as a sole carbon source. J. Chem. Technol. 


\section{Revised Manuscript (With Track Changes)}

559

560

561

562

563

564

565

566

567

568

569

570

571

572

573

574

575

576

Biotechnol.2017, 92, 2538-2545. https://doi.org/10.1002/jctb.5260

[33] Kiely PD, Call DF, Yates MD, et al. Anodic biofilms in microbial fuel cells harbor low numbers of higher-power-producing bacteria than abundant genera. Appl. Microbiol. Biotechnol.2010, 88(1), 371-380. https://doi.org/10.1007/s00253-010-2757-2

[34] Li Y, Yang Y, Jiang W, et al. Integrated treatment of municipal sewage sludge by deep dewatering and anaerobic fermentation for biohydrogenproduction. Environ. Sci. Pollut. Res. 2015, 22(4), 2599-2610. https://doi.org/10.1007/s11356-014-3514-3

[35] Bo T, Zhu X, Zhang L, et al. A new upgraded biogas production process: Coupling microbial electrolysis cell and anaerobic digestion in single-chamber, barrel-shape stainless steel reactor. Electrochem. Commun.2014, 45, 67-70. https://doi.org/10.1016/j.elecom.2014.05.026

[36] Hamelers HVM., Heijne AT, Sleutels THJA, et al. New applications and performance of bioelectrochemical systems. Appl. Microbiol. Biotechnol.2010, 85(6), 1673-1685. https://doi.org/10.1007/s00253-009-2357-1

[37] Cheng S, Xing D, Call DF, et al. Direct biological conversion of electrical current into methane by electromethanogenesis. Environ. Sci. Technol.2009, 43(10), 3953-3958. https://doi.org/10.1021/es803531g

[38] Sangeetha T, Guo Z, Liu W, et al. Cathode material as an influencing factor on beer wastewater treatment and methane production in a novel integrated upflow microbial electrolysis cell (Upflow-MEC). Int. J. Hydrogen Energy, 2016, 41(4), 2189-2196. https://doi.org/10.1016/j.ijhydene.2015.11.111

[39] Wang CT, Chen YM, Hu ZY, et al. Dynamic power response of microbial fuel cells under 


\section{Revised Manuscript (With Track Changes)}

580

external electrical exciting. Int. J. Hydrogen Energy, 2017, 42(34), 22208-22213.

581 https://doi.org/10.1016/j.ijhydene.2017.02.064

582 [40] Gil GC, Chang IS, Kim BH, et al. Operational parameters affecting the performannce of a 583 mediator-less microbial fuel cell. Biosens. Bioelectron.2003, 18(4), 327-334. https://doi.org/10.1016/S0956-5663(02)00110-0

[41] O'Flaherty V, Mahony T, O'Kennedy R, et al. Effect of $\mathrm{pH}$ on growth kinetics and sulfide toxicity thresholds of a range of methanogenic, syntrophic, and sulfate-reducing bacteria. Process Biochem.1998, 33(5), 555-569. https://doi.org/10.1016/S0032-9592(98)00018-1

[42] Cusick RD, Bryan B, Parker DS, et al. Performance of a pilot-scale continuous flow microbial electrolysis cell fed winery wastewater. Appl. Microbiol. Biotechnol.2011, 89(6), 2053-2063. https://doi.org/10.1007/s00253-011-3130-9 


\section{Revised Manuscript (With Track Changes)}

\section{Figures Captions}

591

592 Fig.2. Process changes of COD, ORP, ALK and $\mathrm{pH}$ in $\mathrm{C} 1, \mathrm{C} 2, \mathrm{C} 3, \mathrm{C} 4$ and $\mathrm{C} 5 . \mathrm{C} 1$ to $\mathrm{C} 5$ mean the 593 first to fifth compartment of reactor in flow direction.

594 Fig.3. Contrast of VFAs in (a) the ABR-MECs, (b) conventional ABR.

595

596

597

598

599

600

601

602

Fig.1. Process flow schematic of the ABR-MECs system.

Fig.4. Photograph of scanning electron microscope: (a) 01 , sample from $\mathrm{C} 1$ in the ABR stage, (a) 02 , sample from $\mathrm{C} 1$ in the ABR-MECs stage, (b) 01, sample from C2-C4 in the ABR stages, (b) 02 ,

sample from anodes in the ABR-MECs stage.

Fig.5 Genus of Archaea and Eubacteria in both ABR and ABR-MECs systems: (a) Archaea of middle three compartments in the ABR system and archaea of cathodes in the ABR-MECs system; (b) Eubacteria of middle three compartments in the ABR system and Eubacteria of anodes in the ABR-MECs system.

Fig.6 Relative abundances of functional microbes in both ABR and ABR-MECs systems: 
Revised Manuscript (With Track Changes)

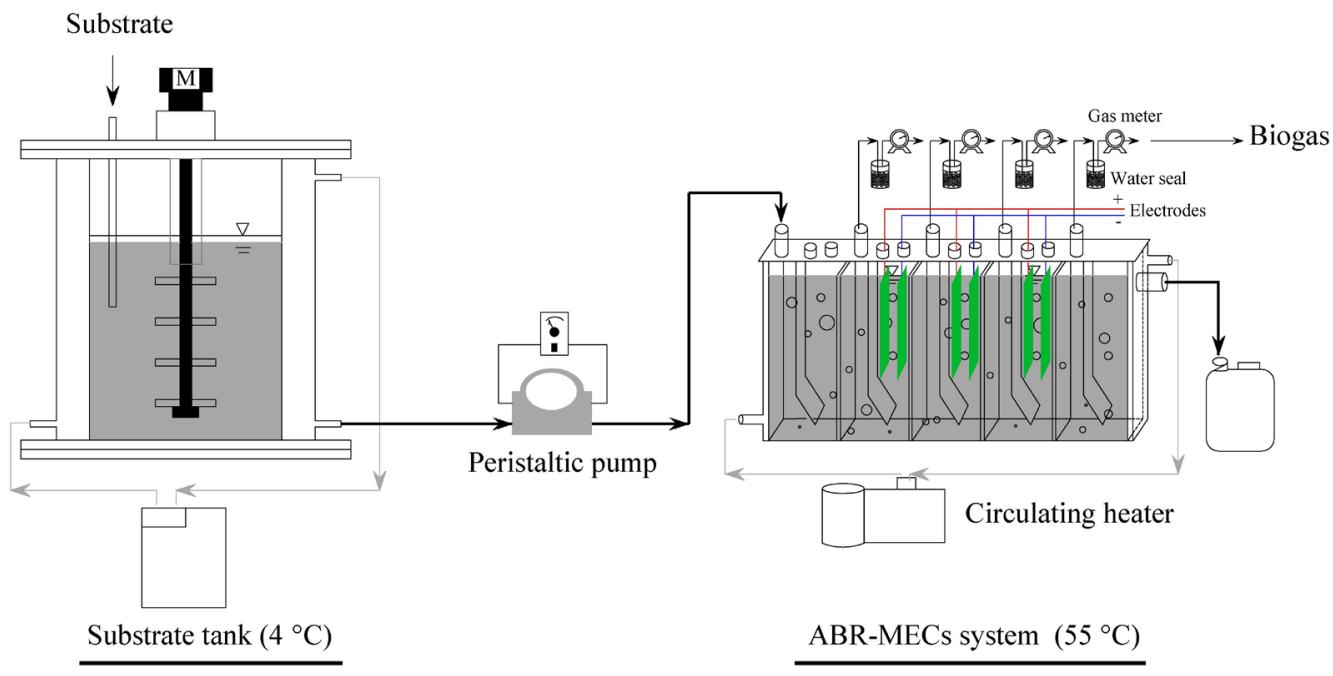

Fig.1 
Revised Manuscript (With Track Changes)

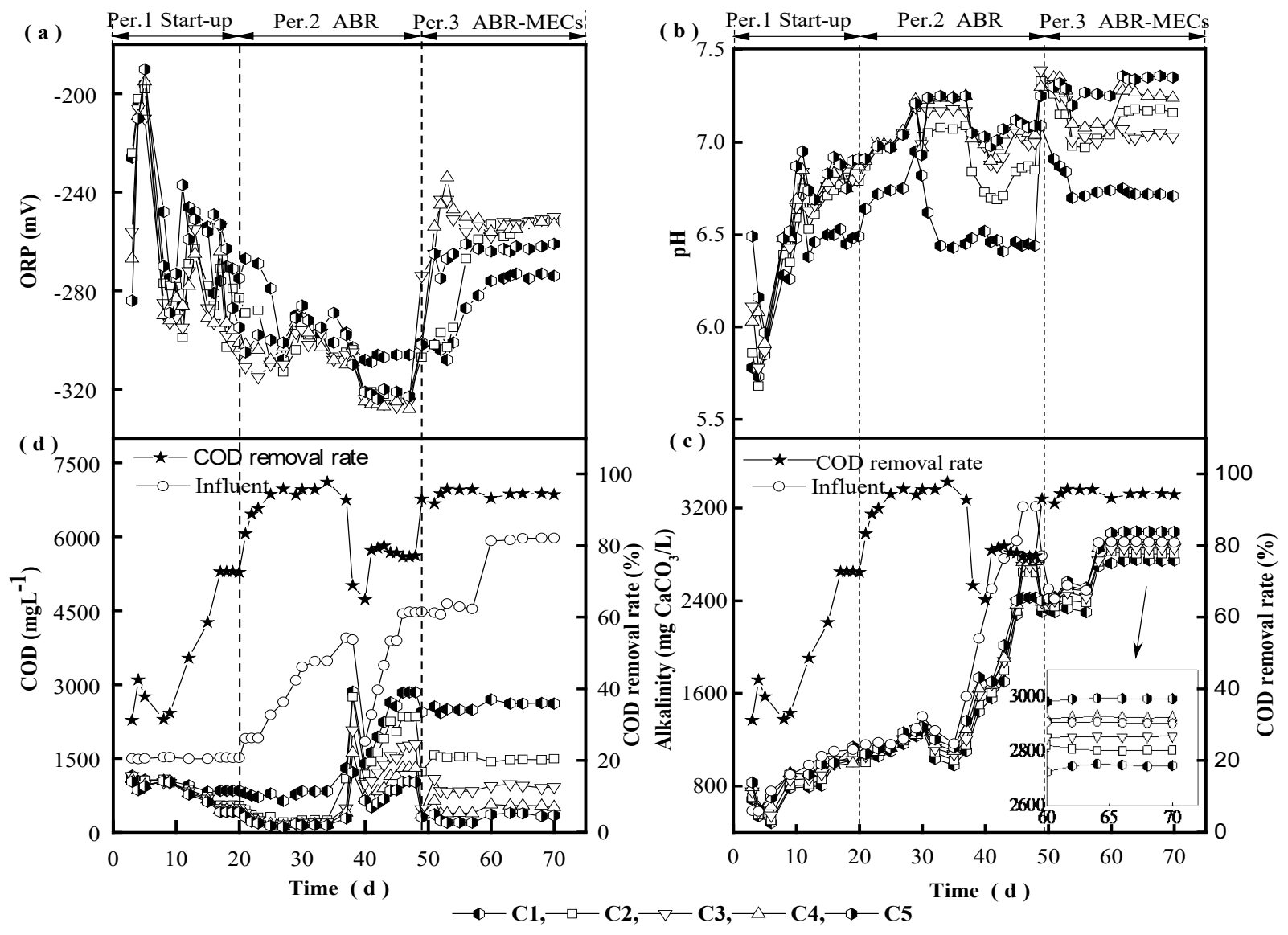

Fig.2 
Revised Manuscript (With Track Changes)

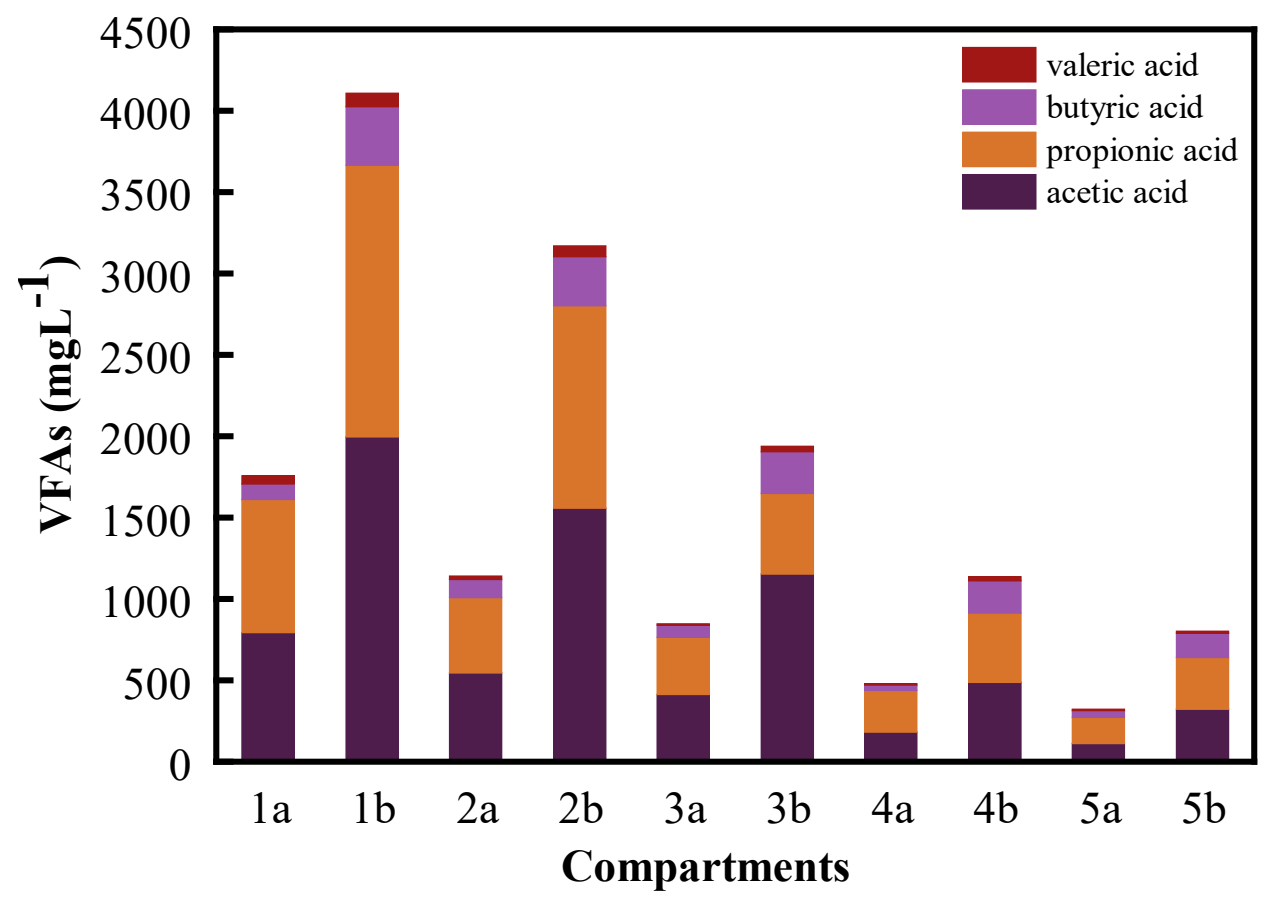

Fig.3 
Revised Manuscript (With Track Changes)


Fig.4 
Revised Manuscript (With Track Changes)

(a)



(b)

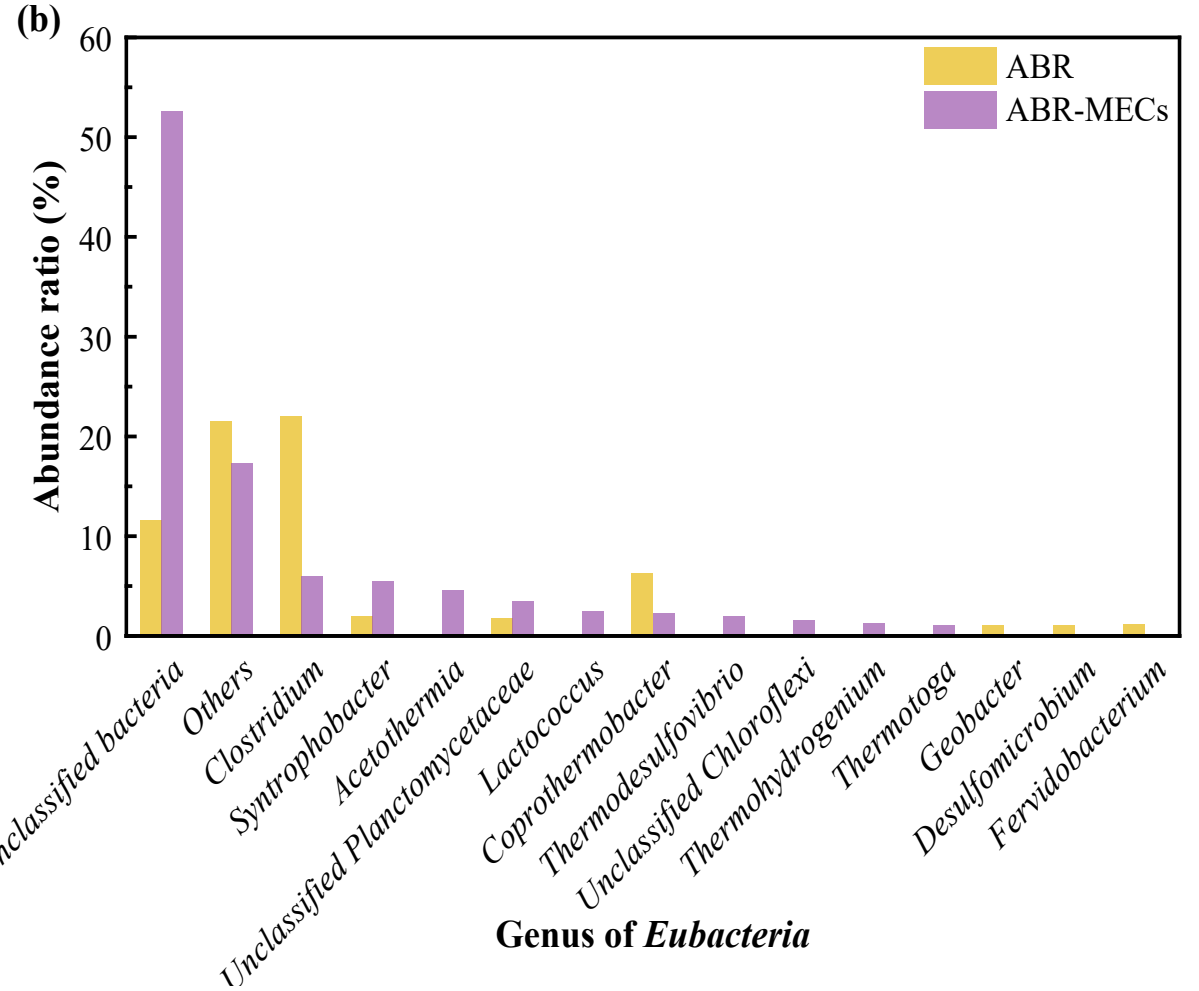

Fig.5 
Revised Manuscript (With Track Changes)



Fig.6 
Revised Manuscript (With Track Changes)

Table 1 Operation of conventional ABR and the ABR-MECs systems

\begin{tabular}{|c|c|c|c|c|c|c|c|}
\hline Stage & Days & $\begin{array}{r}\text { COD } \\
\left(\mathrm{mgL}^{-1}\right)\end{array}$ & $\begin{array}{l}\text { HRT } \\
\text { (h) }\end{array}$ & $\begin{array}{l}\text { OLR } \\
\left(\mathrm{kg} \mathrm{COD} \mathrm{m}^{-3} \mathrm{~d}^{-1}\right)\end{array}$ & $\begin{array}{l}\text { Alkalinity } \\
\left(\mathrm{mg} \mathrm{CaCO}_{3} \mathrm{~L}^{-1}\right)\end{array}$ & $\begin{array}{l}\mathrm{NH}_{4}^{+}-\mathrm{N} \\
\left(\mathrm{mgL}^{-1}\right)\end{array}$ & $\begin{array}{l}\mathrm{PO}_{4}^{3-} \\
\left(\mathrm{mgL}^{-1}\right)\end{array}$ \\
\hline Period.1 & $1-20$ & $\underline{1500 \pm 50}$ & 26 & $\underline{1.4 \pm 0.1}$ & $580-1100$ & $\underline{75 \pm 5}$ & $\underline{5 \pm 1}$ \\
\hline Period. 2 & $21-48$ & $1500-4500$ & 21 & $1.7-5.1$ & $1100-3200$ & $75-225$ & $5-15$ \\
\hline Period.3 & $49-72$ & $4500-6000$ & 21 & $5.1-6.9$ & $2400-2900$ & $225-300$ & $15-20$ \\
\hline
\end{tabular}

Period.1: start-up of conventional ABR, Period.2: conventional ABR system, Period.3: the ABR-MECs system. 
Revised Manuscript (With Track Changes)

Table 2 Process performance for the thermophilic ABR and ABR-MECs systems in the stable state

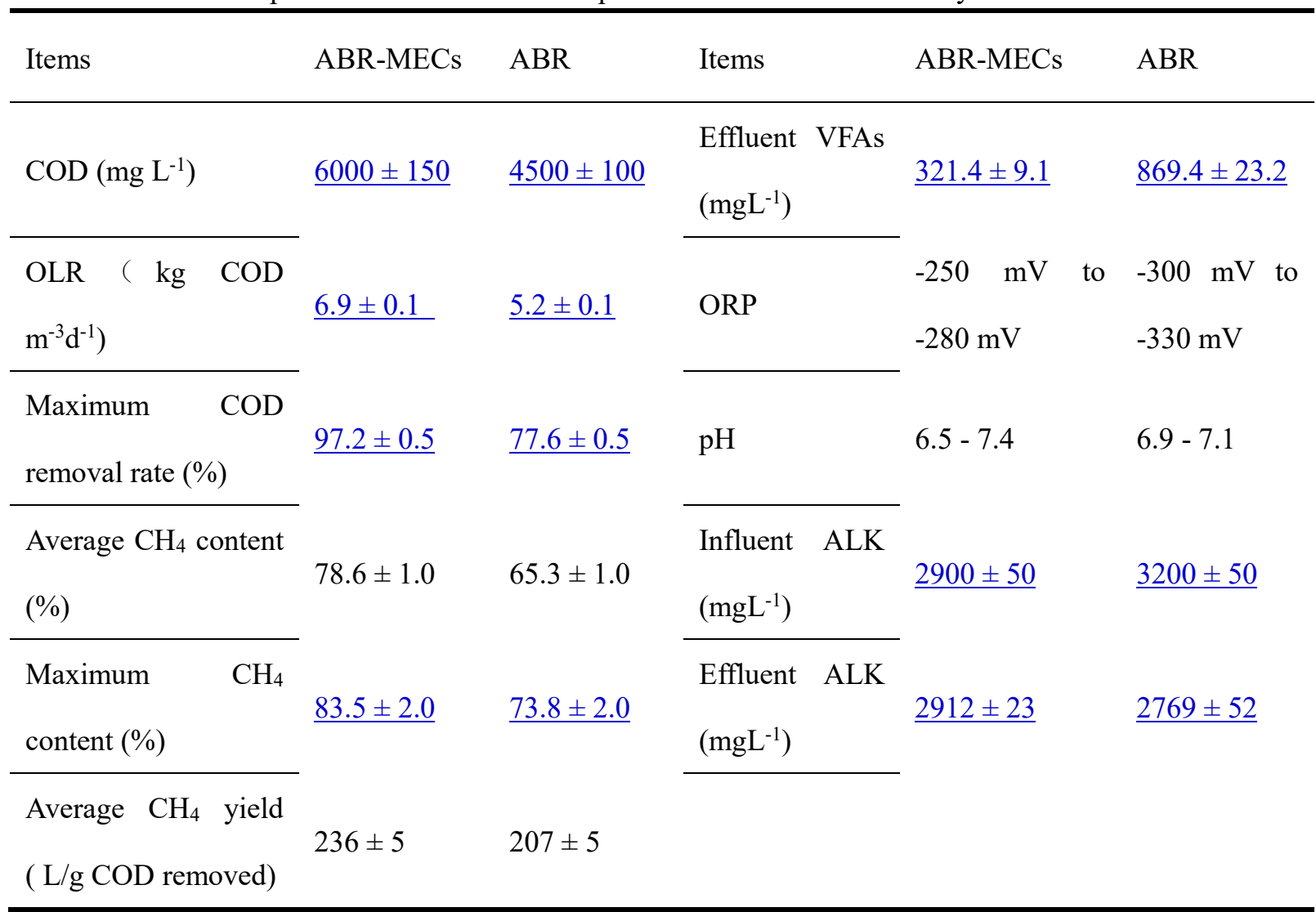

